\title{
Consensus Interferon and Ribavirin in Patients with Chronic Hepatitis C Who Were Nonresponders to Pegylated Interferon alfa-2b and Ribavirin
}

\author{
Carroll B. Leevy
}

Published online: 22 April 2008

(C) Springer Science+Business Media, LLC 2008

\section{Erratum to: Dig Dis Sci}

DOI 10.1007/s10620-007-0076-y

The following errors were published in this article.

1. On page 2, under Study Design, right column, 2nd paragraph, the first and second sentences are incorrect. These 2 sentences currently read, "if patients were HCV RNA negative at 12 weeks, the dose of CIFN was reduced to $15 \mathrm{mcg}$ three times weekly for a further 36 weeks. Patients with a greater than $2 \log$ decrease in HCV RNA were continued on daily CIFN/ribavirin for 36 weeks; treatment was discontinued in patients with a less than 2 $\log$ decrease in HCV RNA." The entire second sentence should be removed and the first sentence should be modified. The below is how the entire paragraph should read:
At 12 weeks, the dose of CIFN was reduced to $15 \mathrm{mcg}$ three times weekly for a further 36 weeks. All patients were followed for 24 weeks after completion of treatment. Patients were provided with the appropriate medication instructions and obtained the study drugs through private pharmacies or other independent providers as dictated by their individual insurance companies.

2. On page 4, right hand column, first paragraph, line 15 , the word "not" is omitted. The sentence reads, "These results are surprising because there is very little difference between the IFN alfa- $2 a$ and IFN alfa- $2 b$ molecules. It should read, "These results are not surprising because..."

The online version of the original article can be found under doi: 10.1007/s10620-007-0076-y.

C. B. Leevy $(\bowtie)$

Department of Medicine, Division of Gastroenterology/

Hepatology, University of Medicine \& Dentistry of New Jersey,

New Jersey Medical School Liver Center, 185 South Orange,

Ave, Newark, NJ 07103, USA

e-mail: leevycb@umdnj.edu 